Environment Conservation Journal 14(3)51-60, 2013

ISSN 0972-3099 (Print) 2278-5124 (Online)

Abstracted and Indexed

\title{
Assessment of spatio-temporal changes in characteristics of industrial waste water in Dehradun region of Uttarakhand
}

\author{
Bharti Ramola $\bowtie$ and Ajay Singh
}

Received: 09.03.2013

Revised: 28.06.2013

Accepted: 27.7.2013

\begin{abstract}
Spatial and temporal changes in the pH, electrical conductivity (EC), TDS, TSS, BOD, COD and concentration of toxic metals viz. cadmium $(\mathrm{Cd})$, iron $(\mathrm{Fe})$, chromium $(\mathrm{Cr})$, lead $(\mathrm{Pb})$, nickel $(\mathrm{Ni})$, zinc $(\mathrm{Zn})$ and copper $(\mathrm{Cu})$ were assessed in the waste water contaminated with untreated or inadequately pretreated industrial effluents from pharmaceutical industries located in Selaqui area and sugar industry and distillery located in Doiwala area of Dehradun. Four effluent samples A, B, C, D collected from manufacturing and processing industries located in the study area and two ground water samples $E_{1} \& E_{2}$ contiguous to Selaqui industrial hub and Doiwala industrial stretch respectively, were analyzed using standard physico-chemical methods. In order to delimit the temporal changes in parameters, samples were collected in three batches at three consecutive seasons of a year. Analyses at STP condition revealed that pH values of ground water samples remained fairly unchanged at $7.01 \pm 0.14 \& 6.98 \pm 0.04$ for $E_{1} \& E_{2}$ respectively, for two regional variations and three seasonal variations. $\mathrm{EC}(\mu \mathrm{mho} / \mathrm{cm})$ varied non-uniformly with highest value of 0.479 observed for sample $A$ in batch 1 whereas lowest value of 0.122 recorded for sample $D$ in batch 3 . TDS in effluents of distillery and sugar industry were found to be 3-6 folds higher than the same for effluents from pharmaceutical industries across all seasons. BOD and COD values for the effluents of distillery and sugar industries were recorded unexpectedly higher than corresponding values in effluents from pharmaceutical industries in all the three batches. TSS was very high in the range of 1500 to $4500 \mathrm{mg} / \mathrm{l}$ in all the effluent samples except the ground water samples. Highest concentration of heavy metal detected was iron with concentration of $10.80 \mathrm{mg} / \mathrm{l}$. $\mathrm{Cr}, \mathrm{Pb}, \mathrm{Cd}$ and $\mathrm{Ni}$ were found to be above the permissible limit recommended by WHO standards. A plausible analysis is made to interpret the wide range variation of the parameters in the light of spatial and temporal change aspects and necessary pretreatment measures to bring down the magnitude of contamination within consent level are suggested.
\end{abstract}

Keywords: Environmental hazard, ground water, heavy metals, industrial waste water, pharmaceutical effluents, physico-chemical parameters

\section{Introduction}

The quality of drinking water in Indian cities has been deteriorated in the recent years mainly due to growth of population and improper disposal of waste water from industries (Tiwari et al., 2008). Furthermore, the groundwater in industrial areas across the country has undergone severe contamination by industrial waste, effluents and emissions which are discharged indiscriminately without any regulatory system (Samina et al., 2004; Parvaze et al., 2009). The untreated sewage, industrial effluents and agriculture wastes are often discharged into the water bodies resulting in wide range of water borne diseases.The agricultural fields around these water bodies too are affected (Chandra and Kulsheshtha, 2004; Tung et al.,

\section{Author's Address}

Department of Chemistry and Environmental Science, Uttaranchal Institute of Technology, Dehradun Email: ramola.bharti570@ymail.com

Copyright by ASEA

All rights of reproduction in any form reserved
2009). It is also well established that the direct and residual effect of manufacturing and processing activities at industries, i.e. pharmaceutical, fertilizer, paper and distilleries have high TDS, acidity or alkalinity, heavy metals i.e. $\mathrm{Cr}, \mathrm{Cd}, \mathrm{As}$, $\mathrm{Hg}, \mathrm{Ni}, \mathrm{Fe}, \mathrm{Mn}$, high BOD and COD (Hassan, 2007). High degree of urbanization and rapid industrial proliferation are the main causative factors for increase in the load of industrial wastewater in city region which when released deteriorates the surface and ground water quality of receiving water bodies (Kamal et al., 1999; Tsagarakis et al., 2001). The Selaqui region of Dehradun in the newly incepted state of Uttarakhand has witnessed setting up of a number of pharmaceutical industries. Also the Doiwala region, a sub urban township in Dehradun, has emerged as an ideal site for industrial processing 
units. The different parameters quantitatively assessed in this work were $\mathrm{pH}$, EC, TDS, TSS, BOD, COD and concentration of toxic metals present in the industrial effluents and ground water samples of the study area .The $\mathrm{pH}$ is an important abiotic parameter and affects the diversity and distribution of aquatic organisms. Its values ranging from 6.7 to 8.4 are suitable while that below 5.0 or above 8.8 are detrimental (Morrison et al., 2001). Electrical conductivity (EC) denotes the capacity of a substance of solution to conduct the electric current. Waste water laden with metal ions and ionic electrolytes typically exhibit dramatic increase in EC values. Water with high dissolved solids has a laxative effect. Total dissolved solids (TDS) include dissolved minerals and salts, humic acid, tannin and pyrogens. The major contributor of TDS is carbonate, bicarbonate, chloride, sulphate, phosphate and nitrate salts. Total suspended solids (TSS) in sewage is organic and mineral particulate matter includes silt, clay, metal oxides sulfides, algae, bacteria and fungi.Waste water from food processing industries, paper and pulp industries has BOD of few thousands of $\mathrm{mg} / \mathrm{l}$, which require several hundred times as much oxygen as is available in pure water (DO present in pure water is $8.4 \mathrm{mg} / \mathrm{l})$. COD (Chemical oxygen demand) value always exceeds BOD value for an effluent and the ratio of COD to BOD is sometimes up to 4 for the effluents of medium scale industries, however the ratio depends upon the activities carried out in the industry and also the raw material used.'Heavy metals' are chemical elements with a specific gravity at least 5 times that of water. When water is contaminated with these heavy metals then that water becomes toxic and dangerous for our biological system (APHA, 1998). Sometimes the toxic heavy metals are present in their varied formulations or in the form of transformed metabolites in effluents of pharmaceutical industries that exerts deleterious effect due to synergism (Singh et al., 2006). Heavy metals have the tendency of strong bio-accumulation and are stored faster than excreted (Dorgham, 1987; Goodbody, 1970). Elaborate studies on ground water pollution by heavy metals have been reported extensively throughout the globe. In the present study, attempt has been made to assess the variation in selected physico-chemical parameters in industrial effluent during different seasons in a year. Also, the impact of these changes on the industrial wastewater has been recorded. Some suggestive treatment measures have also been made to mitigate the deleterious effect an optimal extent.

\section{Material and methods}

Chemicals: All chemicals and reagents of analytical grade (AR grade, Rankem make) were used for analysis. Concentrated $\mathrm{HNO}_{3}$ was used for the digestion of the samples. Metal standards for AAS analyses were used as received [viz. $\mathrm{CdCl}_{2} \cdot \mathrm{H}_{2} \mathrm{O}, \quad \mathrm{Fe}\left(\mathrm{NO}_{3}\right)_{3} \cdot \mathrm{xH}_{2} \mathrm{O}, \quad \mathrm{CuSO}_{4} \cdot 5 \mathrm{H}_{2} \mathrm{O}$, $\mathrm{ZnSO}_{4} \cdot 2 \mathrm{H}_{2} \mathrm{O}, \mathrm{Pb}\left(\mathrm{NO}_{3}\right)_{2}, \mathrm{NiCl}_{2} \cdot 6 \mathrm{H}_{2} \mathrm{O}$ and $\mathrm{Cr}\left(\mathrm{NO}_{3}\right)_{3}$, $3 \mathrm{H}_{2} \mathrm{O}$; Merck (Germany) make] were used as standards in AAS (Hogan, 2010). Reagent solutions were prepared using standard reported procedure.

Instrumentation: The $\mathrm{pH}$ measurements were done using an Elico digital pH meter model LI 120 equipped with a glass $-\mathrm{Ag} / \mathrm{AgCl}, \mathrm{Cl}^{-}(3 \mathrm{M} \mathrm{NaCl})$ electrode. Conductance measurements were done using Elico dual mode (both for EC \& TDS measurement) digital conductivity meter fitted with a conductivity cell. Cell constant kept fixed at 1.01 for all measurements. Calomel electrode \& platinum electrode are used as reference and auxiliary electrodes. TSS was measured by evaporation method. BOD measurement was done by Winkler's method. COD values of the effluents were measured by total oxidative degradation methods using Fenton's reagent. AAS instrument (PERKIN ELMER A. Analyst 200; Germany) attachable to both hollow cathode lamps and electrode less discharge lamps, variable slit width of 0.7-1.2 nm and an air-acetylene flame attaining maximum temperature up to $\approx 2300^{\circ} \mathrm{C}$ was used for the estimation of metals. The samples were analyzed for seven heavy metals namely $\mathrm{Cr}, \mathrm{Ni}, \mathrm{Cd}, \mathrm{Fe}, \mathrm{Zn}$, $\mathrm{Pb}$ and $\mathrm{Cu}$. Analysis wavelength $\lambda(\mathrm{nm}) ; \mathrm{Cr}$ (357.87), Ni (232.0), Cd (228.80), Fe (248.33), Zn (213.86), $\mathrm{Pb}(283.31)$ and $\mathrm{Cu}(324.75)$ by following the procedures given in APHA (1998).

Sampling: Sampling was done as per standard method from various industrial units (represented as $\mathrm{A}, \mathrm{B}, \mathrm{C}, \mathrm{D}, \mathrm{E}_{1} \& \mathrm{E}_{2}$ ) situated in the industrial area i.e. Selaqui region $\left(A, B \& E_{1}\right)$ and Doiwala region $\left(C, D \& E_{2}\right)$ where, $E_{1} \& E_{2}$ are ground water samples contiguous to Selaqui region and Doiwala region respectively. Industrial activities in 
the Selaqui region confine to syntheses of cough syrups, medicinal tablets, therapeutics, packaging materials and cosmetics etc., whereas processing units at Doiwala region is sugar mill and distillery unit. Effluent samples were mostly collected from drains coming out of the industrial site. Plastic cans of 2 liter capacity were used for sampling of effluents. The samples were taken in the 3 batches i.e. during three seasons namely summer, rainy (monsoon) and winter. The data collected were further expressed as seasonal average and the standard deviation were calculated. Samples were collected from the effluent release point or a little away from it (these are basically the sewers coming out from the industrial unit). The collected sample for determination of dissolved oxygen (DO) were collected in BOD bottles and fixed and commenced within 3 hours of collecting the first sample and completed within 72 hours.

Sample preparation: Samples were prepared by following standard methods (APHA, 1998). To ensure removal of organic impurities and prevent interference during analysis, each of $50 \mathrm{ml}$ volume sample was digested using $10 \mathrm{ml}$ concentrated $\mathrm{HNO}_{3}$ in a $250 \mathrm{ml}$ conical flask placed on a fume cupboard. The samples were covered properly with aluminum foil to avoid spillage and heated on a hot plate until the solution reduced to $10 \mathrm{ml}$. This was allowed to cool and made up to mark with distilled water before filtering into a 50-ml standard flask, labeled and made ready for analysis. The blank constituted $5 \% \quad \mathrm{HNO}_{3}$. Standard solutions of different metals were used as supplied. 2-10 ppm solution was prepared after serial dilution of 1000 ppm stock solution. Standard solutions of varied concentration of a metal were aspirated into the AAS through Nebulizer for construction of online calibration plot, using which the concentration of the metal in the unknown sample could be detected automatically.

\section{Results and Discussion}

The average and seasonal variations in water temperature, $\mathrm{pH}, \mathrm{EC}$, TDS, TSS, BOD, COD and concentration of heavy metals are tabulated in Table 1 representing samples in summer, monsoon and winter season. Value of each parameter tabulated is a weighted average of three replicate measurements. Concentration of a particular metal reported in the table is an average of 3 successive and replicate measurements done by the equipment upon single aspiration and the Relative Standard Deviation (RSD) for a measurement was well within the appreciable limit. Significance of spatial and temporal variation in the parametric values is checked by standard ANOVA methods. Spatial and temporal dependence of the parameters are shown in figures: $\mathrm{pH} \& \mathrm{EC}$ (Fig. 1); TDS (Fig. 2); BOD \& COD (Fig. 3); variations in heavy metal concentrations are given in figures 4 to 7 . Among the parameters recorded, $\mathrm{pH}$ values of effluent samples A \& B in season 1 were recorded to be $6.94 \pm 0.11 \& 6.78 \pm 0.13$ respectively, against the values $6.51 \pm 0.09 \& 7.02 \pm 0.12$ for samples $C \& D$ respectively in the same season, showing insignificant spatial variation across the two regions (Fig. 1). This observation is supported by ANOVA $(F=0.0037, \mathrm{df}=2, p>0.996)$ attributed to absence of strong acids and alkalis in the effluents released by the industries of respective region, which otherwise would have caused significant change in $\mathrm{pH}$ values. Similarly, the $\mathrm{pH}$ values exhibited less significant temporal variation $(F=0.0038 ; p>0.05, \mathrm{df}=9)$ across different seasons. Further, the $\mathrm{pH}$ values of the corresponding ground water samples $\mathrm{E}_{1} \& \mathrm{E}_{2}$ also do not show any spatio-temporal variation and remained closer to 7.00 . EC $(\mu \mathrm{mho} / \mathrm{cm})$ values of samples A \& B were found to be higher than the values of $C \& D$ in almost all the three seasons e.g. $(0.211 \pm 0.18 \& 0.251 \pm 0.21 \mu \mathrm{mho} / \mathrm{cm}$ against $0.133 \pm 0.32 \& 0.125 \pm 0.23 \mu \mathrm{mho} / \mathrm{cm}$ in season 1 for A \& B vs. C \& D respectively). This significant spatial trend $(F=1.65 ; p>0.245, \mathrm{df}=2$, Fig. 1$)$ is due to the presence of divalent cations such as $\mathrm{Ca}^{+2} \&$ $\mathrm{Mg}^{2+}$ in appreciable concentrations in pharmaceutical effluents compared to effluents of sugar mill and distillery. EC values of the effluents also showed sizable temporal variation, $(F=1.33$; $p>0.33$, df $=11$, Fig. 1), with the highest value recorded during summer followed by rainy and winter season. This observation is consistent with the high rate of evaporation during summer leading to increased salt accumulation in the pits, ponds where the effluents are being discharged. There was no appreciable change in EC values of all the samples between monsoon and winter owing to intermittent rainfall received in the area during winter (characteristics of Himalayan Terai region) which leads to dilution of the soluble salts. 
Ramola and Singh

Table 1. Values of physico-chemical parameters and concentration of toxic metals* in $1^{\text {st }}$ (summer), $2^{\text {nd }}$ (rainy) and $3^{\text {rd }}$ (winter) batch effluent/ground water samples

\begin{tabular}{|c|c|c|c|c|c|c|c|c|c|c|c|c|c|c|c|c|c|c|}
\hline \multirow{2}{*}{ } & \multicolumn{3}{|c|}{$\begin{array}{r}\text { Effluent } \\
\text { sample-A }\end{array}$} & \multicolumn{3}{|c|}{$\begin{array}{c}\text { Effluent } \\
\text { sample-B }\end{array}$} & \multicolumn{3}{|c|}{$\begin{array}{c}\text { Effluent } \\
\text { sample-C }\end{array}$} & \multicolumn{3}{|c|}{$\begin{array}{c}\text { Effluent } \\
\text { sample-D }\end{array}$} & \multicolumn{3}{|c|}{$\begin{array}{c}\text { Water sample- } \\
\mathbf{E}_{1} \\
\end{array}$} & \multicolumn{3}{|c|}{$\begin{array}{c}\text { Water sample- } \\
\mathrm{E}_{\mathbf{2}}\end{array}$} \\
\hline & $=\frac{\frac{0}{0}}{\pi}$ & 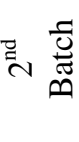 & $\because \frac{\overline{0}}{\tilde{D}}$ & $-\frac{\tilde{0}}{\tilde{E}}$ & ڤ & m & $-\frac{\frac{0}{0}}{n}$ & $\stackrel{\frac{c}{0}}{\stackrel{0}{\pi}}$ & $\because \frac{\frac{\pi}{0}}{n}$ & $-\frac{0}{0}$ & 규 & $\approx \frac{0}{0}$ & $=\frac{\frac{5}{0}}{\tilde{n}}$ & 를 & क ज & $=\frac{\frac{\tilde{J}}{\tilde{E}}}{\oplus}$ & त & in \\
\hline $\begin{array}{l}\text { Temp } \\
\left({ }^{\circ} \mathrm{C}\right)\end{array}$ & 27.1 & 24.8 & 20.8 & 27.0 & 25.1 & 21.1 & 27.2 & 25.0 & 21.0 & 26.9 & 24.8 & 20.9 & 27.0 & 24.1 & 21.1 & 27.1 & 24.0 & 21.0 \\
\hline pH & $\begin{array}{c}6.94 \\
\pm \\
0.11\end{array}$ & $\begin{array}{c}6.51 \\
\pm \\
0.43\end{array}$ & $\begin{array}{c}6.56 \\
\pm \\
0.09\end{array}$ & $\begin{array}{c}6.78 \\
\pm \\
0.13\end{array}$ & $\begin{array}{c}7.02 \\
\pm \\
0.32\end{array}$ & $\begin{array}{c}7.01 \\
\pm \\
0.13\end{array}$ & $\begin{array}{c}6.51 \\
\pm \\
0.09\end{array}$ & $\begin{array}{c}6.11 \\
\pm \\
0.51\end{array}$ & $\begin{array}{c}6.00 \\
\pm \\
0.08\end{array}$ & $\begin{array}{c}7.02 \\
\pm \\
0.12\end{array}$ & $\begin{array}{c}7.6 \\
\pm \\
0.64\end{array}$ & $\begin{array}{c}7.80 \\
\pm \\
0.17\end{array}$ & $\begin{array}{c}7.17 \\
\pm \\
0.13\end{array}$ & $\begin{array}{c}6.95 \\
\pm \\
0.56\end{array}$ & $\begin{array}{c}6.91 \\
\pm \\
0.12\end{array}$ & $\begin{array}{c}7.03 \\
\pm \\
0.08\end{array}$ & $\begin{array}{c}6.98 \\
\pm \\
0.7\end{array}$ & $\begin{array}{c}6.95 \\
\pm \\
0.06\end{array}$ \\
\hline $\begin{array}{l}\text { EC } \\
(\mu \mathrm{mho} / \mathrm{c} \\
\mathrm{m})\end{array}$ & $\begin{array}{c}0.47 \\
\pm \\
0.08\end{array}$ & $\begin{array}{c}0.21 \\
\pm \\
0.18\end{array}$ & \begin{tabular}{|c|}
0.29 \\
\pm \\
0.13 \\
\end{tabular} & $\begin{array}{c}0.37 \\
\pm \\
0.10\end{array}$ & $\begin{array}{c}0.25 \\
\pm \\
0.21\end{array}$ & $\begin{array}{c}0.25 \\
\pm \\
0.09\end{array}$ & \begin{tabular}{|c|}
0.21 \\
\pm \\
0.07
\end{tabular} & $\begin{array}{c}0.13 \\
\pm \\
0.32\end{array}$ & $\begin{array}{c}0.22 \\
\pm \\
0.08\end{array}$ & $\begin{array}{c}0.25 \\
\pm \\
0.12\end{array}$ & \begin{tabular}{|c|}
0.12 \\
\pm \\
0.23
\end{tabular} & \begin{tabular}{|c|}
0.12 \\
\pm \\
0.05
\end{tabular} & $\begin{array}{c}0.17 \\
\pm \\
0.06\end{array}$ & \begin{tabular}{|c|}
0.38 \\
\pm \\
0.41
\end{tabular} & $\begin{array}{c}0.39 \\
\pm \\
0.12\end{array}$ & $\begin{array}{c}0.22 \\
\pm \\
0.06\end{array}$ & \begin{tabular}{|c|}
0.37 \\
\pm \\
0.32 \\
\end{tabular} & \begin{tabular}{|c|}
0.43 \\
\pm \\
0.16
\end{tabular} \\
\hline $\begin{array}{l}\text { TDS } \\
(\mathbf{p p m})\end{array}$ & $\begin{array}{c}429 \\
\pm \\
18\end{array}$ & $\begin{array}{c}265 \\
\pm \\
13\end{array}$ & $\begin{array}{c}272 \\
\pm \\
24\end{array}$ & $\begin{array}{c}418 \\
\pm \\
33\end{array}$ & $\begin{array}{l}325 \\
\pm \\
24\end{array}$ & $\begin{array}{c}345 \\
\pm \\
29\end{array}$ & $\begin{array}{c}1265 \\
\pm \\
76\end{array}$ & $\begin{array}{c}1398 \\
\pm \\
131\end{array}$ & $\begin{array}{c}1099 \\
\pm \\
79\end{array}$ & $\begin{array}{c}1325 \\
\pm \\
110\end{array}$ & $\begin{array}{c}1198 \\
\pm \\
110\end{array}$ & $\begin{array}{c}1200 \\
\pm \\
67\end{array}$ & $\begin{array}{c}117 \\
\pm \\
8\end{array}$ & $\begin{array}{c}452 \\
\pm \\
43\end{array}$ & $\begin{array}{c}455 \\
\pm \\
43\end{array}$ & $\begin{array}{c}135 \\
\pm \\
12\end{array}$ & $\begin{array}{c}614 \\
\pm \\
53\end{array}$ & $\begin{array}{c}531 \\
\pm \\
42\end{array}$ \\
\hline $\begin{array}{l}\text { BOD } \\
(\mathrm{mg} / \mathrm{l})\end{array}$ & $\begin{array}{c}41 \\
\pm \\
3\end{array}$ & $\begin{array}{c}56 \\
\pm \\
6\end{array}$ & $\begin{array}{c}55 \\
\pm \\
6\end{array}$ & $\begin{array}{c}40 \\
\pm \\
5\end{array}$ & $\begin{array}{l}17 \\
\pm \\
3\end{array}$ & $\begin{array}{l}22 \\
\pm \\
4\end{array}$ & $\begin{array}{c}580 \\
\pm \\
26\end{array}$ & $\begin{array}{c}564 \\
\pm \\
42\end{array}$ & $\begin{array}{c}380 \\
\pm \\
39\end{array}$ & $\begin{array}{c}497 \\
\pm \\
34\end{array}$ & $\begin{array}{c}502 \\
\pm \\
34\end{array}$ & $\begin{array}{c}250 \\
\pm \\
24\end{array}$ & $\begin{array}{c}34 \\
\pm \\
6\end{array}$ & $\begin{array}{c}45 \\
\pm \\
6\end{array}$ & $\begin{array}{c}45 \\
\pm \\
6\end{array}$ & $\begin{array}{c}53 \\
\pm \\
9\end{array}$ & $\begin{array}{l}75 \\
\pm \\
8\end{array}$ & $\begin{array}{c}54 \\
\pm \\
8\end{array}$ \\
\hline COD & $\begin{array}{c}242 \\
\pm \\
16 \\
\end{array}$ & $\begin{array}{c}327 \\
\pm \\
23\end{array}$ & $\begin{array}{c}328 \\
\pm \\
33\end{array}$ & $\begin{array}{c}236 \\
\pm \\
26\end{array}$ & $\begin{array}{c}92 \\
\pm \\
10\end{array}$ & $\begin{array}{c}90 \\
\pm \\
8\end{array}$ & $\begin{array}{c}1940 \\
\pm \\
178\end{array}$ & $\begin{array}{c}1788 \\
\pm \\
136\end{array}$ & $\begin{array}{c}326 \\
\pm \\
45\end{array}$ & $\begin{array}{c}1220 \\
\pm \\
109\end{array}$ & $\begin{array}{c}1090 \\
\pm \\
113\end{array}$ & $\begin{array}{c}225 \\
\pm \\
31\end{array}$ & $\begin{array}{c}26 \\
\pm \\
3\end{array}$ & $\begin{array}{c}30 \\
\pm \\
4\end{array}$ & $\begin{array}{c}35 \\
\pm \\
6\end{array}$ & $\begin{array}{c}49 \\
\pm \\
5\end{array}$ & $\begin{array}{c}67 \\
\pm \\
4\end{array}$ & $\begin{array}{c}44 \\
\pm \\
7\end{array}$ \\
\hline $\begin{array}{l}\mathrm{Cr} \\
\text { (ppm) }\end{array}$ & 0.28 & 0.29 & 0.31 & 0.18 & 0.15 & 0.18 & $\begin{array}{c}0.00 \\
1 \\
\end{array}$ & ND & ND & 0.12 & 0.21 & 0.22 & ND & ND & ND & ND & ND & ND \\
\hline $\begin{array}{l}\mathrm{Pb} \\
(\mathrm{ppm})\end{array}$ & 0.18 & 0.18 & 0.18 & 0.21 & 0.21 & 0.21 & 0.17 & 0.17 & 0.18 & 0.17 & 0.18 & 0.26 & 0.13 & 0.15 & 0.16 & 0.24 & 0.11 & 0.21 \\
\hline $\begin{array}{l}\text { Cd } \\
(\mathrm{ppm})\end{array}$ & 0.62 & 0.55 & 0.58 & 0.18 & 0.16 & 0.19 & ND & 0.00 & ND & 0.08 & 0.09 & 0.11 & ND & ND & ND & $\begin{array}{c}0.08 \\
7\end{array}$ & ND & ND \\
\hline $\begin{array}{l}\mathrm{Cu} \\
(\mathrm{ppm})\end{array}$ & 0.35 & 0.32 & 0.38 & 0.16 & 0.18 & 0.14 & 0.12 & 0.09 & 0.23 & 0.16 & 0.11 & 0.20 & 0.07 & 0.05 & 0.07 & 0.12 & 0.03 & 0.12 \\
\hline $\begin{array}{l}\mathbf{Z n} \\
(\mathbf{p p m})\end{array}$ & 1.16 & 1.13 & 1.13 & 0.98 & 0.96 & 0.98 & 1.34 & 1.27 & 1.31 & 1.28 & 1.05 & 1.08 & 0.39 & 0.34 & 0.35 & 0.43 & 0.41 & \begin{tabular}{|l|}
0.47 \\
\end{tabular} \\
\hline $\begin{array}{l}\text { Ni } \\
\text { (ppm) }\end{array}$ & 0.05 & 0.03 & 0.05 & 0.07 & 0.06 & 0.08 & ND & ND & ND & 0.07 & 0.09 & 0.09 & ND & ND & ND & ND & ND & ND \\
\hline $\begin{array}{l}\mathrm{Fe} \\
\text { (ppm) }\end{array}$ & 8.5 & 8.6 & 8.8 & 8.7 & 10.8 & 9.3 & 8.9 & 10.2 & 10.8 & 8.6 & 10.5 & 10.7 & 8.1 & 8.3 & 7.8 & 8.0 & 8.1 & 8.1 \\
\hline
\end{tabular}

$\mathrm{ND}=$ Not within the detection limit; * Standard deviation values of analyses not included as the values themselves are least square weighted average and regression done automatically by the equipment with RSD less than 5\%.
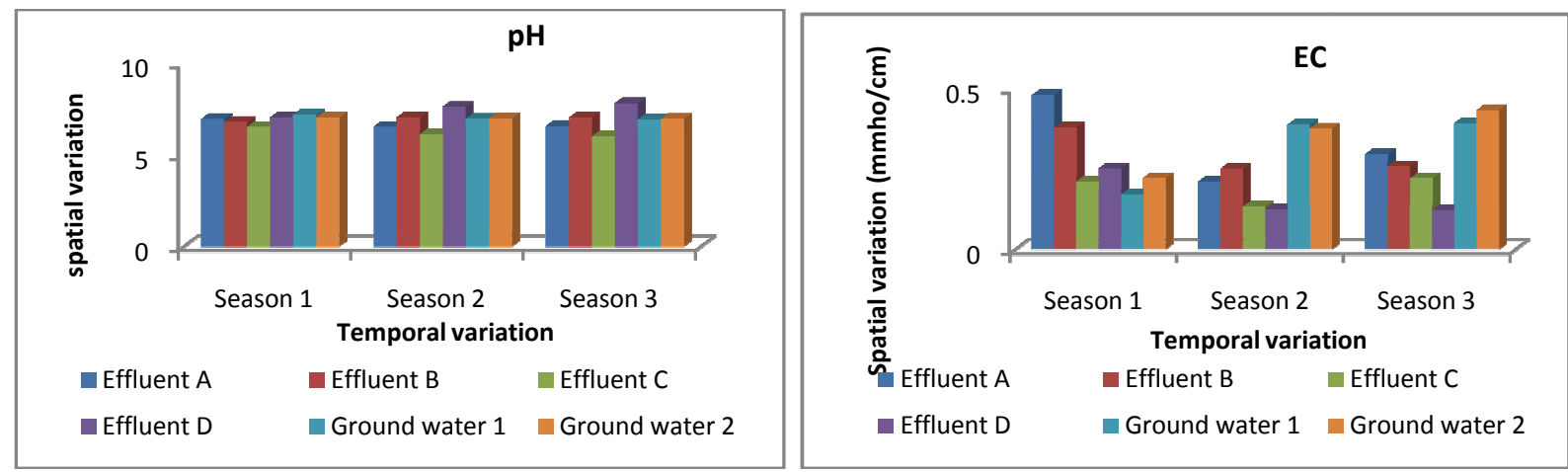

Fig.1: Spatio-temporal variation in $\mathrm{pH}$ and $\mathrm{EC}$ values of effluent samples and ground water samples 
It is noteworthy that presence of bi or trivalent heavy metal ions, which were analyzed by AAS in the present study, hardly influences the EC value of the effluents because of their abysmal low concentration in ppm-ppb range. EC of ground water samples of the two regions show a significant spatial variation $(F=38.56 ; \mathrm{df}=2, p>0.007)$ with the relatively higher value near Doiwala because of the pervious nature of aquifers in this region which augments pace of percolation of the soluble salt solution reaching the associated water table. Another reason may be the stagnancy of the salt laden industrial waste water in ponds and pits which get enough time to seep into the water table. Nevertheless, sewerage system in the industrial region of Selaqui is relatively well managed to divert the waste water into running water before penetrating into water table. EC of ground water also showed a temporal variation $(F=0.072, \mathrm{df}=5$; $p>0.8$ ) with a highest value recorded in monsoon and winter season than in summer.

TDS (ppm) values in effluents of distillery and sugar industry were found to be approximately 3-6 fold higher than the same for effluents from pharmaceutical industries across all seasons, viz. $(429+18$ \& $418+33$ ppm for samples A \& B against $1265 \pm 76 \& 1325+110 \mathrm{ppm}$ for $\mathrm{C} \& \mathrm{D}$ in season 1$)$. This significant spatial variation $(F=0.061, \mathrm{df}=2$; $p>0.94$, Fig. 2) is ascribed to presence of dissolved minerals and salts, humic acid, tannin and pyrogens in addition to salts like carbonate, bicarbonate, chloride, sulphate, phosphate and nitrate in high concentration in the effluents of sugar industry and distillery. Absence of organic residues is expected in pharmaceutical effluents due to antagonistic nature of the ingredients towards humus formation and consequently lower TDS values were observed. TDS (ppm) values also exhibited a less significant temporal variation $(F=84.715, \mathrm{df}=11 ; p<2.1 \mathrm{E}-06$, Fig. 2) with relatively higher value during summer $(1325 \pm 110,1198 \pm 110 \& 1200 \pm 67 \mathrm{ppm}$ for sample $\mathrm{D}$ in summer, monsoon \& winter seasons respectively), which may be ascribed to the increased activity of microorganisms on the effluent contents in summer leading to accumulation of organic residues and humus formation, whereas microbial activity is largely inhibited during seasons with low diurnal temperature. Analogous trend in spatial variation
$(\mathrm{F}=18.67, \mathrm{df}=2 ; p>0.02)$ in TDS is observed for ground water samples of the two regions. TDS values of sample $E_{2}$ was found to be higher than sample $E_{1}$ in all the three seasons. But, TDS values of ground water showed a significant temporal variation $(F=0.211, \mathrm{df}=5 ; p>0.669)$ with highest value in monsoon season, when the rate of recharging the water table is maximum. A notable inference can be drawn from this trend that the TDS content of ground water is largely guided by the surface water TDS values, and particularly in region like Dehradun valley, where highly chargeable unconfined aquifers are the part of geological formations and aquifer zone is not covered by a zone of thick overlying aquicludes.

TSS (mg/l) was found to be in the very high range (1500-4500) in all the samples except ground water samples, due to presence of silt, clay, metal oxides, metal sulfides, algae, bacteria and fungi. Significance in spatial and temporal variation could not be observed probably due to haphazard TSS values obtained for the samples. This can be explained by the fact that the ingredients responsible for imparting TSS values to effluents are significantly influenced by anthropogenic intervention rather than the solitary effluent inherent characteristics. TSS values of ground water samples were fairly low due to sorption capacity of the clay content in the strata above the water table. Mechanical filtration in the flow channels of fissured and krastified rocks of aquifer are also responsible for elimination of suspended bacteria and fungi present in water reaching the water table.

BOD (mg/l) values for the effluents of sugar industries and distillery were recorded unexpectedly higher than corresponding values in effluents from pharmaceutical industries in all the three batches. Reason for $>7-10$ fold increase in BOD values in the samples C \& D than A \& B $(41 \pm 3 \& 40 \pm 5 \mathrm{ppm}$ for samples A \& B against $580 \pm 26 \& 497 \pm 34 \mathrm{ppm}$ for $\mathrm{C} \& \mathrm{D}$ in season 1) lies in the type of processing activities accomplished in the industries. Effluents of distilleries and sugar industries carry large amount of biodegradable substances yet to be decomposed or partially decomposed stuffs to be feasted upon by bacteria and hence imparts high BOD values, whereas pharmaceutical effluents do not contain such ingredients to large extent. Spatial variation 
$(F=0.249, \mathrm{df}=2 ; p>0.78$, Fig. 3$)$ in BOD values of effluents is industry specific rather than geomorphic. BOD values also exhibited strong temporal variation $(F=22.08, \mathrm{df}=11 ; p=3.17 \mathrm{E}-04$, Fig. 3) with the highest value recorded during summer, when the production activity at its maximum and consequently, the rate of release of wastes outweighs rate of removal of the biodegradable stuffs from the effluent.BOD values of the ground water samples also showed strong spatial variation $(F=0.623, \mathrm{df}=2 ; p>0.59)$. Sample $\mathrm{E}_{2}$ posted higher value than sample $\mathrm{E}_{1}$ across all the three seasons. BOD value of ground water is largely guided by the composition of surface water and its intensity of pollution. However, there is a reasonable decrease in the values from surface waste water to ground water contiguous to it. The biochemical degradation of organic and inorganic pollutants is accomplished by micro-organisms which live in small quantities in the natural ground water milieu and augment rapidly when the supply of nutrients is raised by pollution (Golwer, 1975). Bacteria and viruses which accompany the waste material are unable to survive or multiply in such an environment where antagonistic microorganisms are present and hence, are gradually eliminated from the ground water. These bacteria and viruses also tend to move through a porous media containing silt and clay (Drewry and Eliassen, 1968; Romero, 1970) and hence, depending on the geological environment, are further removed from the ground water. Temporal variation $(F=5.76$, $\mathrm{df}=5 ; p>0.074)$ in BOD values shown by the groundwater samples is solely due to differential action of microorganisms towards degradation of wastes present in the overlade surface waste water which recharges the ground water.COD $(\mathrm{mg} / \mathrm{L})$ values of effluent samples showed significant spatial $(F=1.224, \mathrm{df}=2 ; p>0.338$, Fig. 3) and temporal variation. COD values in almost all effluents exceeded corresponding BOD values across all seasons, supporting the proposition that substantial amount of inorganic chemicals also present apart from organic compounds. Higher COD values were obtained for effluent $C \& D$ than $\mathrm{A} \& \mathrm{~B}$ due to higher amount of organic residues in the effluents of sugar mill and distillery than pharmaceutical effluents. Similar spatial trend was found in BOD values of two groups of effluents. Temporal pattern in COD values $(F=3.333, \mathrm{df}=11$; $p>0.07$, Fig. 3) also concomitant with BOD temporal pattern with the highest value recorded during summer followed by monsoon and winter season.COD values of ground water sample showed insignificant variation both spatially and temporally. Further, the values of $E_{1} \& E_{2}$ in all the three seasons are far less than the values of corresponding effluents, owing to the fact that concentration of chemical compounds gets attenuated before reaching the water table by combination of self purification processes viz. microbial decomposition, chemical coprecipitation, sorption, exchange of gases and mechanical filtration. Decrease in COD values is primarily due to precipitation and co-precipitation of inorganic elements and compounds e.g. $\mathrm{Fe}(\mathrm{OH})_{3}$ and $\mathrm{Mn}$ got precipitated, whereas $\mathrm{Cu}, \mathrm{Pb}, \mathrm{Zn}$, As, $\mathrm{W}, \mathrm{V}$, Fluorides and phosphates are co-precipitated in the oxidation zone ( $E_{h}$ is positive) of ground water and thus eliminated. Similarly, the reduction zone ( $E_{h}$ is negative) of ground water is conducive for eliminating heavy metal ions. Data given in Table 1 indicate that most of the metals were found in varying concentrations. Figure 4 to 7 show spatio-temporal variation of heavy metals. Chromium varied from 0.12 to $0.31 \mathrm{ppm}$ in all effluent samples. The EPA standard for total $\mathrm{Cr}$ is $0.1 \mathrm{ppm}$, while $0.05 \mathrm{ppm}$ as per WHO standards, in this way it is observed that $\mathrm{Cr}$ is above the permissible standard value in most of the effluent samples. If $\mathrm{Cr}$ is discharged continuously then it will increase in ground water, although it is not detectable at present in either of the hand pump water samples $E_{1} \& E_{2}$. Increase in chromium concentration in drinking water may lead to allergic dermatitis and cancer of bladder, lungs and skin (Hanaa et al., 2000).

Lead $(\mathrm{Pb})$ was found to be in the range of 0.158 to $0.262 \mathrm{ppm}$ which is well above the permissible limit (0.01 ppm as per WHO standards). It was also observed in the higher than consent concentration range in hand pump water sample $\mathbf{E}_{\mathbf{1}}$ taken from the pharmaceutical industrial stretch (Selaqui area) of Dehradun valley. $\mathrm{Pb}$ is known to be a very toxic metal and it tends to interfere with a variety of body processes and is toxic to many organs and tissues including the heart, bones, intestine, kidneys, reproductive and nervous systems (Jayaraman et al., 2003). 


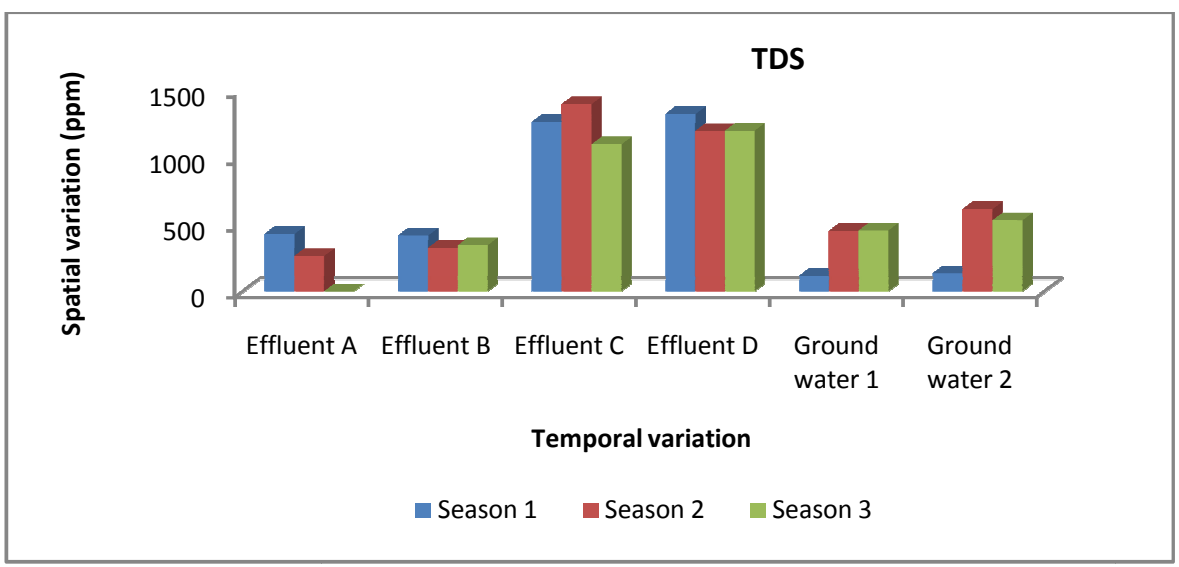

Fig. 2: Spatio-temporal variation in TDS values of effluent samples and ground water samples
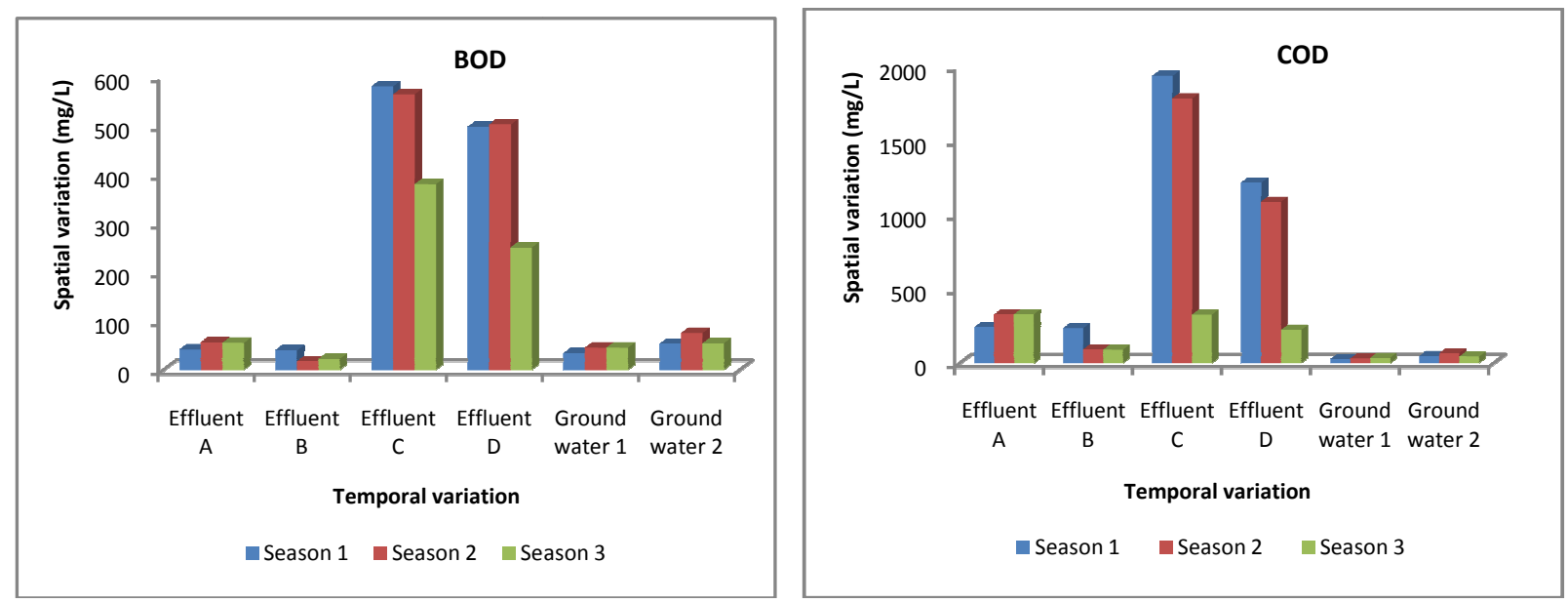

Fig. 3: Spatio-temporal variation in BOD and COD values of effluent samples and ground water samples
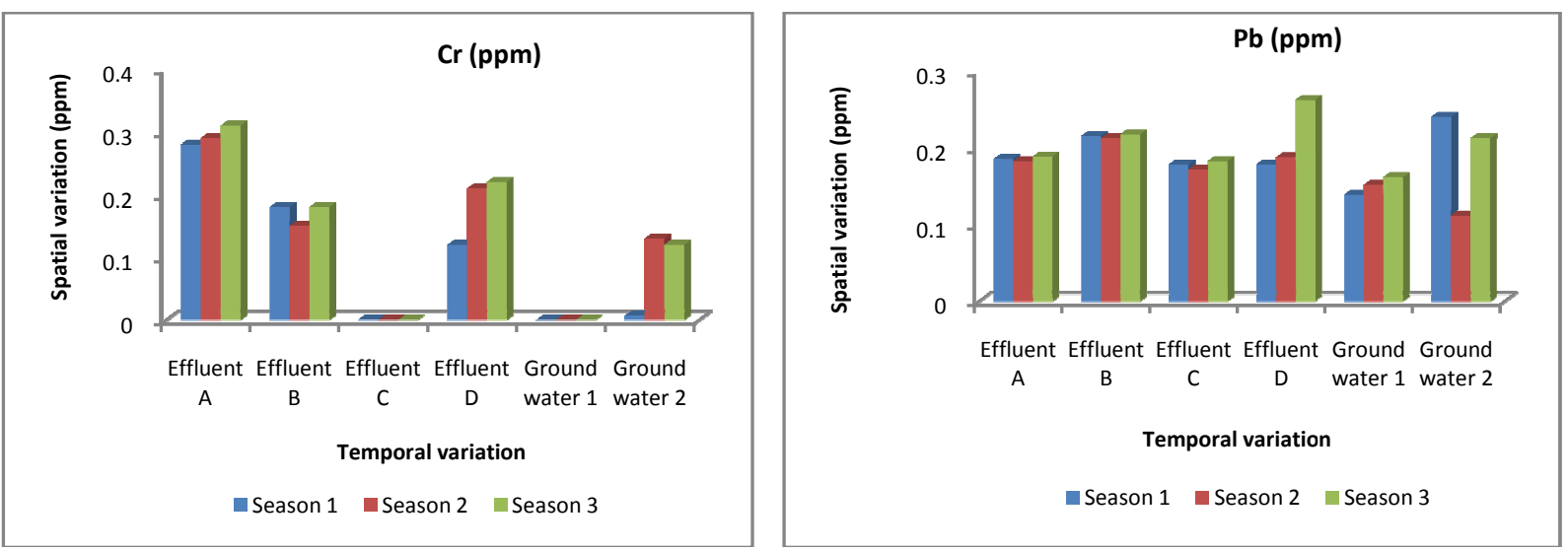

Fig. 4: Spatio-temporal variation of $[\mathrm{Cr}]$ and $[\mathrm{Pb}]$ in effluent samples and ground water samples. 

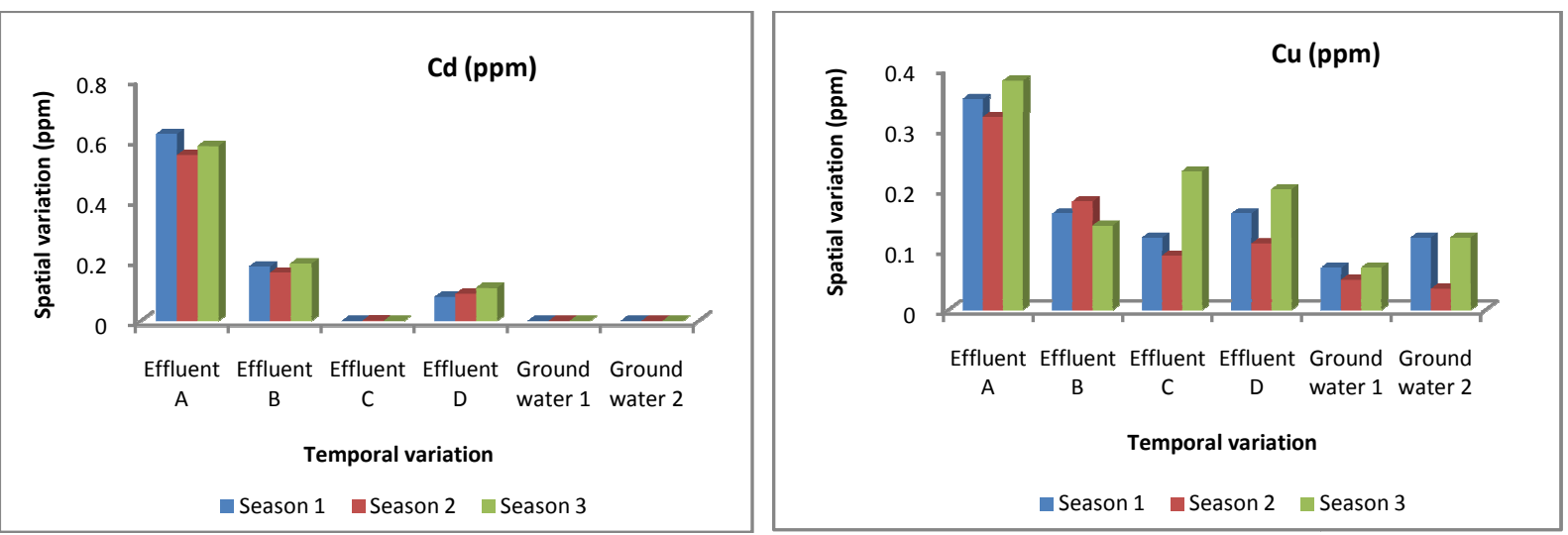

Fig. 5: Spatio-temporal variation of $[\mathrm{Cd}]$ and $[\mathrm{Cu}]$ in effluent samples and ground water samples.
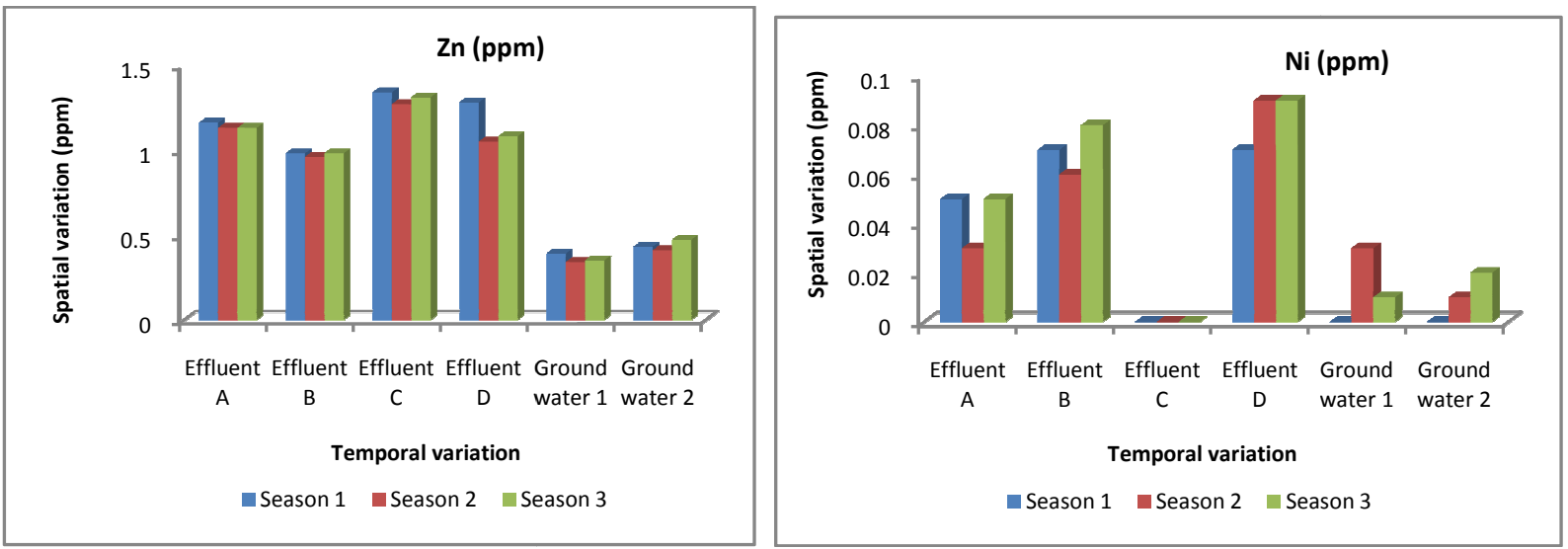

Fig. 6: Spatio-temporal variation of $[\mathrm{Zn}]$ and $[\mathrm{Ni}]$ in effluent samples and ground water samples.

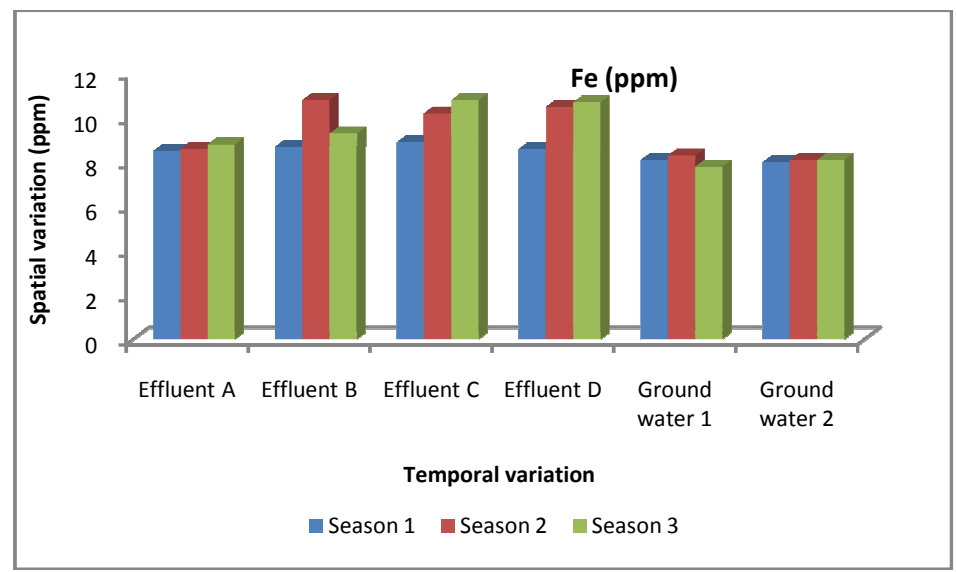

Fig.7: Spatio-temporal variation of [Fe] in effluent samples and ground water samples.

Nickel (Ni) was observed in the range from 0.05 to Ground water samples also contain trace amount of $0.12 \mathrm{ppm}$, which appears to be higher than the cadmium. Acute exposure to Cd fumes may cause WHO prescribed limit of $0.02 \mathrm{ppm}$. Ni was not flu like symptoms including chills, fever and detected in the ground water samples.Cadmium muscle ache. More severe exposure can cause (Cd) was found in the range of 0.001-0.62 ppm. rachea-bronchitis, pneumonititis and pulmonary 
edema. Zinc (Zn) was observed in the range of 0.96 to $1.31 \mathrm{ppm}$ in all effluent samples which is in the permissible range. Although Zinc being a cofactor of digestive enzymes such as carbonic anhydrase, is essential for human health but too much $\mathrm{Zn}$ can cause health problems, like stomach cramps, skin irritation, vomiting, nausea and anemia.In humans, the liver is the primary organ of copper-induced toxicity. Other target organs include bone and the central nervous and immune system (James, 1996). Excess copper intake also induces toxicity indirectly by interacting with other nutrients (Oyeku, et al., 2010). Excess copper intake produces anemia by interfering with iron transport and/or metabolism (Pandey et al, 2010). Copper was found in the range of 0.08 to $0.38 \mathrm{ppm}$ in the effluent samples while it was present in below detection limit in hand pump water sample i.e. $\mathrm{Cu}$ was found lower than the prescribed limit of $2 \mathrm{ppm}$. Excess copper intake causes stomach upset, nausea, and diarrhea and can lead to tissue injury and disease (Odiete, 1999). The permissible range of iron in drinking water is $10 \mathrm{ppm}$. Concentration of Fe detected in samples and ground water is almost reaching the permissible limit of $10 \mathrm{ppm}$ of iron content (WHO, 1996).From the Figures 6-12, it is evident that four heavy metals i.e $\mathrm{Cr}, \mathrm{Pb}, \mathrm{Cd}$ and $\mathrm{Ni}$ were observed to be in the higher range in most of the pharmaceutical industry effluent samples of the study area. Adequate effluent treatment measures have to be taken to bring down the concentration of these heavy metals within the consent level so that imminent health hazards due to heavy metal induced toxicity can be delayed, if not eliminated. Suggested pretreatment measures for the effluents: In addition to conventional physical methods (James, 1990) of pretreating industrial wastes viz., adsorption, reverse osmosis, floatation, ion exchange and ultra filtration, new technologies of metal removal has to be adopted, which make use of the metal-binding capacities of microorganisms such as yeast, algae, bacteria and aquatic flora. A new technology of using Sphagnum moss to selectively remove $\mathrm{Al}, \mathrm{Cd}, \mathrm{Zn}, \mathrm{Ca}, \mathrm{Mn}$ and $\mathrm{Mg}$ to concentrations below that of potable water has been developed by US Bureau of mines. Chemical methods used for treatment of wastes include precipitation of metals by $\mathrm{Ca}(\mathrm{OH})_{2}, \mathrm{NaOH} \&$ $\mathrm{Na}_{2} \mathrm{CO}_{3}$ may be adopted. Chlorine can be used for oxidation, $\mathrm{Al}_{2}\left(\mathrm{SO}_{4}\right)_{3} \& \mathrm{FeSO}_{4}$, for solid separation.

Sedimentation with the use of lime in the removal of metals from waste water can be substantiated from the fact that it reduces concentration of $\mathrm{Fe}$, $\mathrm{Cu}, \mathrm{Cr}, \mathrm{Pb}, \mathrm{Hg}, \mathrm{Ni}$ and $\mathrm{Zn}$ by $80 \%, 60 \%, 58 \%$, $55 \%, 50 \%, 15 \%$ and $70 \%$ respectively (James, 1990).Effluent samples with high TSS, BOD are recommended to undergo primary treatment so that $2 / 3^{\text {rd }}$ of SS and $1 / 3^{\text {rd }}$ of BOD go into the sludge. Many of the other pollutants like metals and chlorinated organic compounds tend to absorb onto the solids, so that around $70-80 \%$ of those will go to sludge. When the BOD value of effluents is greater than $1000 \mathrm{mg} / \mathrm{L}$, anaerobic oxidative treatment process is recommended. Now a days, USAB (Up flow Activated Sludge Blanket Reactor) and anaerobic filters are increasingly being in use, hence recommended for the industries in our context. Stringent measures need to be adopted by the Government with regard to industrial effluent composition and industries should be cautioned to adhere to the norms framed from time to time, otherwise they should be heavily penalized (Goodbody, 1970; Hasan, 2007).

\section{Conclusion}

Spatial and temporal variation in physico-chemical parameters of the effluent samples of Selaqui and Doiwala industrial region of Dehradun, Uttarakhand was assessed by different analytical techniques. Almost all parameters except $\mathrm{pH}$ showed significant variation spatially and with season. Significance of variation was checked by standard ANOVA. Intensity of pollution in the industrial waste water was checked by depicting a comparison with the analogous parametric values of ground water sample collected contiguous to the respective industrial region. Concentration of toxic heavy metals in the effluent samples and ground water samples analyzed by AAS technique was compared with the permissible limit delimited by global agencies like EPA \& WHO. Toxic metal concentration was found to have exceeded the consent limit in few effluent samples. Ground water samples taken from hand pump situated in the industrial area were found to contain most of the heavy metals within the permissible range. Suitable waste treatment procedures are recommended to bring down the level of contamination within the environmental tolerance limit. 


\section{Ramola and Singh}

\section{Acknowledgement}

We are grateful to ICFAI University, Dehradun and Thapar Industries, Yamunanagar for helping in the analysis of the samples.

\section{References}

APHA, 1998. Standard Methods for the Examination of Water and Wastewater, $19^{\text {th }}$ Ed.. American Public Health Association, AWWA, WEF Washington D. C. Glanze WD, 1996, Mosby Medical Encyclopedia, Revised Edition 1996

BIS, 1983. Indian standard specifications for drinking water, IS: 10500, Bureau of Indian Standards, New Delhi.

Chandra, P. and Kulsheshtha, K., 2004. Chromium Accumulation and Toxicity in Aquatic Vascular Plants Botanical Review, 70(3): 313-327.

Dorgham, M.M., 1987. Phytoplankton in an area of multipolluting factors west of Alexandria, Egypt, Qatar Univ. Sci. Bull., 7: 393-419.

Drewry W.A. and Eliassen R., 1968. Virus movement in groundwater, J. Water Pollut. Control Fed., (40): 257 271.

Golwer Arthur, Matthess Georg and Schneider Wilhelm. Effects of waste deposits on groundwater quality. Groundwater Pollution - Symposium - Pollution des Eaux Souterraines (Proceedings of the Moscow Symposium, August 1971; Actes du Colloque de Moscou, Août 1971): IAHS-AISH Publ. No. 103, 1975.

Goodbody, I.M., 1970. The biology of Kingston Harbour. $\boldsymbol{J}$. Sci. Res. Council Jamaica, 1: 10-34.

Hanaa, M., Eweida, A and Farag, A., 2000. Heavy metals in drinking water and theirenvironmental impact on human health. International Conference on Environmental Hazards Mitigation, Cairo University, Egypt,: 542-556.

Hasan, S.H, Talat, M and Rai S., 2007. Sorption of cadmium and zinc from aqueous solution by water hyacinth (Eichchornia crassipes). Biores Technol., 98: 918-928.

James G., 1990.Wastewater technology fact sheet, United States Environment Protection Agency, Office of water, Washington D.C. EPA 832F.

James G.,1996. CO in the Early Universe Clouds Cosmologists'Views. Science, 273: 581.

Kamal M.M, Malmgren-Hansen A. and Badruzzaman A.B.M., 1999. Assessment of Pollution of the River Buriganga, Bangladesh, Using a Water Quality Model, Water Sci. Technol., 40 (2):129-136.
Morrison G, Fatoki O. S, Person L and Ekberg A., 2001. Assessment of the Impact of Point Source Pollution from the Keiskammahoek Sewage Treatment Plant on the Keiskamma River - pH, Electrical Conductivity, Oxygendemanding Substances (COD) and Nutrients, Water Res., 27( 4): 475-480.

Odiete WO, (1 ${ }^{\text {st }}$ ed.)1999. Impacts associated with water pollution in Environmental Physiology of Animals and Pollution. Diversified Resources Ltd, Lagos, pp. 187-219.

Oyeku, O.T \& Eludoyin, A.O.,2010. Heavy metal contamination of ground water resources in a Nigerian urban settlement. African Journal of Environmental Science and Technology, 4 (4): 201-214.

Pandey, J.,Shubhashish, K \& Pandey, R.2010. Heavy metal contamination of Ganga river at Varanasi in relation to atmospheric deposition. Tropical Ecology, 51(2): 365373 .

Parvaze, A.W., Mohammad, S.K. and Zaidi, A., 2009. Chromium Reduction, plant growth promoting potentials and metal solubilization by Bacillus. Sp. isolated from alluvial soil, Current Microbiology, 54: 237-243.

Romero, J.C.,1970. "The Movement of Viruses Through Porous Media",Groundwater,8(4):37-48.

Samina J, Jaffar M, Shah M H., 2004. Physico-chemical profiling of ground water along Hazara strip, Pakistan. $J$. Chem. Soc., 26(3): 288-292.

Singh, A., Saxena, S., Gaur, S. \& Chauhan, R.K. 2006. Biological Effect of Heavy metal in drinking water of Shivalik \& western UP regions in India, Chemical Weekly, 1:193-197.

Tiwari, K., Dwivedi, S., Mishra, S., Srivastava, S., Tripathi, R., Singh, N., et al., 2008. Phytoremediation efficiency of Portulaca tuberosa rox and Portulaca oleracea L. naturally growing in an industrial effluent irrigated area in Vadodra, Gujrat, India. Environmental Monitoring and Assessment, 147, (1): 15-22.

Tsagarakis K.P, Mara D.D and Angelakis A.N., 200.Wastewater Management in Greece:Experience and Lessons for Developing Countries,Water Sci. Technol.,44,(6):163-172.

Tung, P.G.A., Yusoff, M.K., Majid, N.M., Joo, G.K. and Huang, G.H., 2009. Effect of Nitrogen and Potassium fertilizers o $\mathrm{n}$ nutrient leaching and groundwater quality under mature oil palm in Sabah during the Monsoon Period, American Journal of Applied Sciences, 6(10): 1788-1799.

WHO. 1996. Guideline for drinking water quality. Second edn. Vol.2. Health criteria and other reporting information, World Health Organization, Geneva. 